\title{
Physical and chemical bases of decarburization of high-carbon ferromanganese melt
}

Величко О.Г., Ду Юньшен, Мяновська Я.В., Камкіна Л.В., Анкудінов Р.В. Фізичні та хімічні основи зневуглецювання високовуглецевого феромарганцевого розплаву

\begin{abstract}
Метою роботи є встановлення фрізико-хімічних закономірностей поведінки вуглецю, кремнію, марганцю при застосуванні методу продувки киснем високовуглецевого фреромарганцю. Методика. Розглянуто процес продувки рідкого металу киснем. При продувці розплаву киснем відбувається переважне окислення кремнію. Його присутність в металі практично блокує окислення марганцю. Оскільки кисень $є$ асиміляційним газом, процеси змішування компонентів ванни конвертера і відновлення оксидів марганцю на кордоні розділу металилак не отримують належного розвитку під час продування.

Плавки середньовуглецевого феромарганцю в конвертері з дуттям характеризуються стабільним хімічним складом і майже повністю відповідають вимогам для цього типу сплаву. Невелике перевищення концентрації кремнію в металі по ряду плавок можна легко усунути шляхом додаткової продувки ванни киснем на заключній стадії рафрінування.Поведінка фоосфору в цих плавках не контролюється. Вміст P2O5 в кінцевому шлаку становить 0,1\%. Для досягнення прийнятних концентрацій фосфору в металі необхідно використовувати вихідні матеріали з низьким вмістом фоссрору. Наукова новизна. Беручи до уваги високу спорідненість кремнію до кисню, фрізичну та хімічну основу для виробництва середньовуглецевого фреромарганцю, а також металевого марганцю та низьковуглецевого феромарганцю, відбувається процес взаємодії оксидів марганцю певний основний розплав шлаку з кремнієм, розчиненим у феромарганці (марганиі), тобто як комбінований процес відновлення-рафрінування для отримання фреросплавів марганцю із заданим стандартом вмісту кремнію

Ключові слова: фреромарганець, продувка киснем, фосфрор, шлак, термодинаміка

The aim of the work is to establish physicochemical patterns of behavior of carbon, silicon, manganese when using the method of oxygen purge of high-carbon ferromanganese. Method. The process of blowing red metal to sour is neglected. With the fusion of fused acid, it is more important to oxidize silicon. Its presence in metal is practical in the block of oxidized manganese. Because oxygen is an assimilation gas, the mixing processes of the converter bath components and the reduction of manganese oxides at the metal-slag interface do not develop properly during purging.

The smelters of the medium-carbonaceous ferromanganese in the converter are characterized by a stable chemical warehouse and even a higher number of vimogs for this type of alloy. The low concentration of silicon in metal over a number of swimming trunks can be easily shoved with a hat of pre-purge bathtub with sour at the final stage of refining. The behavior of phosphorus in these smelts is not controlled. The content of P2O5 in the final slag is $0.1 \%$. To achieve acceptable concentrations of phosphorus in the metal, it is necessary to use starting materials with a low phosphorus content. Scientific novelty. Taking into consideration the high affinity of silicon for oxygen, the physical and chemical basis for the production of medium-carbon ferromanganese, as well as metallic manganese and low-carbon ferromanganese, is the process of the interaction of manganese oxides of a certain basicity slag melt with silicon dissolved in ferromanganese (manganese), that is, as combined reduction -refining process to produce manganese ferroalloys with a given silicon content standard

Key words: ferromanganese, oxygen purge, phosphorus, slag, thermodynamics
\end{abstract}

\section{Introduction.}

Manganese ferroalloys, which are produced in Ukraine, are widely used in the smelting of steel and alloys, mainly in the form of ferromanganese and ferrosilicon manganese. When smelting a number of steel grades, it is necessary to use ferromanganese with a reduced carbon content - medium- and lowcarbon ferromanganese.

The initial high-carbon ferromanganese for oxidative refining from carbon to obtain mediumcarbon ferromanganese must have a low content of phosphorus and silicon. These requirements may be met by high-carbon ferromanganese produced with the use of low-phosphorous manganese ore charge and preliminarily refined from silicon with oxygen before pouring it into a converter for further decarburization. As previous studies have shown, medium-carbon ferromanganese after oxidative decarburization of high-carbon ferromanganese of the

Величко Олександр Григорович - чл.-кор НАНУ, ректор НМетАУ

Ду Юншен - аспірант НМетАУ

Мяновська Яна Валеріївна - к.т.н., доц. НМетАУ

Камкіна Людмила Володимирівна - д.т.н.,проф. НМетАУ

Анкудінов Руслан Валентинович - к.т.н., доц. НМетАУ common composition from Nikopol oxidic concetrates, as a rule, has a high phosphorus content, which limits the use of medium-carbon ferromanganese in steelmaking. Therefore, to obtain medium-carbon ferromanganese with a regulated by standard low $(0.1 \% \mathrm{P})$ and decreased $(<0.4 \% \mathrm{P})$ phosphorus content, it is necessary to use highcarbon ferromanganese smelted with lowphosphorous manganese ore (imported) or lowphosphorus manganese charge slag, that significantly increases the cost of initial ferromanganese and, as a result, medium-carbon ferromanganese.

Among other requirements for the initial highcarbon ferromanganese, the low silicon content is of primary importance. In the process of blowing the melt, silicon is oxidized in the first minutes of ferromanganese conversion. The resulting silica interacts with manganese oxide, increases the chemical aggressiveness of the slag melt in relation to the 
periclase lining. Acidic slag, interacting with basic lining, reduces its stability, thus necessitating the use expensive highly refractory periclase refractories, including electromelted magnesite (periclase).

The increased silicon content in the initial highcarbon ferromanganese increases the amount of $\mathrm{SiO} 2$ in the slag, that is accompanied by a high consumption of lime, which should also have a low silica content to reduce the slag ratio and the loss of manganese with waste slag. To reduce metal loss at the gas phase, the oxidative conversion of low-silicon high-carbon ferromanganese for carbon oxidation must be carried out under a rational temperature regime. The aim of the work is to establish physicochemical patterns of behavior of carbon, silicon, manganese when using the method of oxygen purge of high-carbon ferromanganese

Theoretical studies of decarburization of a high-carbon ferromanganese melt.

In solid high-carbon initial ferromanganese ( 8\% $\mathrm{C})$, carbon is represented by carbide $[\mathrm{Mn}, \mathrm{Fe}]_{7} \mathrm{C}_{3}$. In liquid manganese, carbon is dissolved in a significant amount. At the temperature of $1773 \mathrm{~K}$, the solubility of carbon in liquid manganese is $7.892 \%$, and at $1873 \mathrm{~K}$ it is $8.116 \%$. [1] When producing a number of steels and alloys, it is necessary to have ferromanganese which has low carbon content Currently, medium- and low-carbon ferromanganese are obtained by silicon reduction of manganese oxides due to silicon of ferrosilicon manganese [2].

The process of decarburization of liquid ferromanganese with gaseous oxygen can be generally represented by the reaction:

$$
\begin{aligned}
& 2[\mathrm{C}]_{\mathrm{Mn}}+\mathrm{O}_{2}=2 \mathrm{CO}, \\
& K_{O_{2}}=\frac{P_{C O}^{2}}{a_{C}^{2} P_{O_{2}}^{2}}, \\
& \text { where } a_{C}=\gamma_{C} X_{[C]}
\end{aligned}
$$

In the case of oxidation of carbon dissolved in manganese, the reaction of its interaction with $\mathrm{MnO}$ is the following:

$$
\begin{aligned}
& {[\mathrm{C}]_{M n}+(M n O)=[M n]+C O,} \\
& K_{M n O}=\frac{a_{[M n] \cdot P}(C O}{a_{[C]} \cdot a_{(M n O)}}, \\
& a_{[M n]}=\gamma_{[M n]} X_{[M n]} .
\end{aligned}
$$

The calculation of the activity coefficients $\gamma_{[C]}$ and $\gamma_{[M n]}$ depending on the silicon content in ferroman anese can be carried out according to the equations [3]:

$$
\begin{aligned}
& \ln \gamma_{[C]}=\left(1-x^{2}\right) \cdot\left[-0.745-0.97 x-55.9 x^{2}+771 x^{3}-1432 x^{4}\right. \\
& \ln \gamma_{[M n]}=x^{2}\left[4.5+85 x-904 x^{2}+1531 x^{3}\right.
\end{aligned}
$$

In studies, liquid manganese and graphite have been taken as the standard state [3]. In the calclatins, the values of saturated solutions of carbon in manganese can be taken as the standard state [4].

The study of the activity of manganese and carbon by the equilibrium method of the $\mathrm{Mn}-\mathrm{C}$ system melt with solid $\mathrm{MnO}$ oxide and the gas phase of Ar-CO with controlled partial pressure of $\mathrm{CO}$ by the reaction [5],

$$
\begin{aligned}
& {[\mathrm{C}]_{M n}+M n O \text { solid }=[M n] \text { sol }+C O,} \\
& K_{P}=\frac{a_{M n} \cdot P C O}{a_{[C]_{M n}} \cdot a_{M n O}},
\end{aligned}
$$

has established the equilibrium constant of the above reaction and the concentration dependences

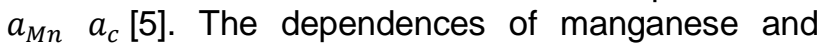
carbon activity coefficients on the manganese and carbon molar fractions in the alloy are described by the equation:

$$
\begin{gathered}
\ln \gamma_{M n}=5,47 x^{2}-46,0 x^{3} \\
\ln \gamma_{C}=-0,291-10,9 x+75 x^{2}-46,8 x^{3}
\end{gathered}
$$

Oxidative refining of high-carbon ferromanganese in an oxygen bottom-blown converter has shown [6] that the ratio $[\% \mathrm{Mn}] /[\% \mathrm{C}]$ depends on temperature, and this dependence is satisfactorily described by the equation:

$$
\lg \frac{[\% M n]}{[\% C]}=-\frac{10115}{T}+6,70
$$

With increasing temperature, the carbon content decreases, but at the same time, the manganese vapor pressure also increases significantly, that follows from the equation

$$
\lg P_{M n}=-\frac{12546}{T}+10,483 \text { (Па) }
$$

The decarburization of ferromanganese with gaseous oxygen should be carried out at relatively moderate temperatures to reduce the loss of manganese due to evaporation and the rate of carbon oxidation with the reduction of manganese loss due to evaporation should be matched.

Refining of high-carbon ferromanganese with manganese ore and high manganese slag melts was carried out by pioneering studies of V.A. Boholiubov [7.8]. High-carbon ferromanganese mixed with manganese ore was melted in an electric steel furnace. The chemistry of the refining process is quite simple, and does not require the production of ferrosilicon manganese, which is attractive for enterprises that smelt ferromanganese only.

According to N.V. Tolstoguzov [9], the change in the Gibbs energy of the interaction reaction of $\mathrm{MnO}$ with carbon dissolved in manganese has the form:

$$
M n O+(1+x)[C]_{M n}=M n C_{x}+C O,
$$


$\Delta G_{T}^{\circ}=196293-123.0 \cdot T, \mathrm{~J} / \mathrm{mol}$.

The theoretical equilibrium temperature of this reaction, taken as the reaction initiation temperature, is $1597 \mathrm{~K}\left(1324^{\circ} \mathrm{C}\right)$.

The authors [10] explain the difficulties in obtaining refined high-carbon ferromanganese by oxidative refining due to the formation of a carbon solution in manganese during the interaction of liquid manga?ese with carbon monoxide.

As shown in the paper [11], the interaction react?on of carbon from high-carbon ferromanganese with manganese oxide can be appreciably developed even at a temperature of $1600^{\circ} \mathrm{C}$, and a content of $2 \%$ can be achieved at a temperature of about $1750^{\circ} \mathrm{C}$. Due to the tense heat balance, refining of high-carbon ferromanganese with air did not receive industrial implementation. However, the ideas laid down in experiments for blowing ferromanganese melt with air were developed in subsequent works on decarburization of ferromanganese with gaseous oxygen.

The results of experimental studies. Decarburization of high-carbon ferromanganese with oxygen in a ladle and in an induction furnace

When refining [12] ferromanganese in IST-0.16 furnace and in a ladle, gaseous oxygen has been blown. During the blowing the melt, the dependence of the change in the ratio [\% $] /[\% \mathrm{Mn}]$, which depends on temperature, was established. The process of decarburization of ferromanganese was convntionally divided into three periods.

In the first period, silicon and manganese were oxidized by top-blown gaseous oxygen supplied to the ferromanganese melt, which was accompanied by the formation of slag and the intense evolution of red fume, consisting of dusty particles of manganese oxides. As a result of the exothermicity of silicon and manganese oxidation reactions, the melt temperature increased to $1540-1560^{\circ} \mathrm{C}$. However, the carbon content in the ferromanganese melt practically did not change. Only at the end of the first period, the flame from $\mathrm{CO}$ burning appear, it was considered a sign of the start of carbon burning.

In the second period, carbon began to oxidize intensively and the flame from CO burning increased. Manganese oxide of the slag was spent on carbon oxidation by the reaction

$(\mathrm{MnO}) \mathrm{sl}+[\mathrm{C}]_{\mathrm{FMn}}=[\mathrm{Mn}]_{\mathrm{FMn}}+$ COgas

and until the end of the second period, the $\mathrm{MnO}$ content decreased markedly. The temperature of the metal increased to $1680-1720^{\circ} \mathrm{C}$.

In the third period, the co-oxidation of carbon and manganese took place. The CO flame decreased and the amount of red fume increased. The temperature increased to $1750-1820^{\circ} \mathrm{C}$.

During the blowing, the ratio $[\% \mathrm{C}] /[\% \mathrm{Mn}]$ remained constant up to $1540-1560^{\circ} \mathrm{C}$, which indicates the practical absence of decarburization of high-carbon

$\begin{array}{lllllllll}\text { Heat } & \mathrm{MnO} & \mathrm{SiO}_{2} & \mathrm{CaO} & \mathrm{MgO} & \mathrm{FeO} & \mathrm{C} & \mathrm{P} & \% \mathrm{CaO} / \% \mathrm{SiO}_{2} \\ 4 & 50,0 & 14,72 & 23,5 & 7,72 & 1,78 & 0,08 & 0,064 & 1,59 \\ 5 & 45,1 & 18,52 & 24,3 & 7,00 & 1,52 & 0,04 & 0,045 & 1,31\end{array}$

ferromanganese. An increase in the temperature of the ferromanganese melt occurred due to the further oxidation of manganese. The increase in temperature was accompanied by a significant decrease in the ratio $[\% \mathrm{C} /[\% \mathrm{Mn}]$, which indicated the intensive development of the decarburization of ferromanganese. At $1700-1800^{\circ} \mathrm{C}$, the ratio $[\% \mathrm{C}] /[\% \mathrm{Mn}]$ changed insignificantly; therefore, the decarburization reaction of ferromanganese in the industrial amount faded out and mainly manganese continued to be oxidized [11]. The authors [11] has generalized the results of research melts on high-carbon ferromanganese refining from carbon by top-blown oxygen and has shown that the manganese content in the alloy increased with decreasing carbon concentration. The phosphorus fraction increased by $0.05-0.1 \%$. Large losses of manganese during the smelting of manganese alloys are caused, as noted above, by high vapor pressure $-13.33 \mathrm{kPa}$ at $1560^{\circ} \mathrm{C}$ and 66.65 $\mathrm{kPa}$ at $1820^{\circ} \mathrm{C}$ [13.2].

When refining ferromanganese by oxygen blowing, up to $10 \% \mathrm{Mn}$ is oxidized and lost with dust (\% by mass) in which manganese is contained in the form of $\mathrm{Mn}_{2} \mathrm{O}_{3}$ :

$\begin{array}{lllll}\mathrm{Mn}_{2} \mathrm{O}_{3} & \mathrm{SiO}_{2} & \mathrm{MgO} & \mathrm{FeO} & \mathrm{P}\end{array}$ 94-96 $1,0 \quad 1,5 \quad 1,5-2,0 \quad 0,03-0,05$

The use of high-carbon ferromanganese with a low silicon content (less than 1\%) as the initial alloy for decarburization is associated with a deterioration in the heat balance and additional losses due to manganese oxidation and its loss with slag. Therefore, high-carbon ferromanganese in experiments for oxygen blowing is used with a silicon content of ( $\geq 2.0-2.5 \%)$.

In order to clarify the specifics of high-carbon ferromanganese decarburization (with a content of $2.5-4.0 \% \mathrm{Si}$ ) when blown with oxygen [12], it was established that at blowing silicon carbon ferrm?nganese with oxygen, silicon is oxidized primarily, manganese is oxidized simultaneously, but to a lesser extent. In this case, despite a significant increase in temperature to $1650-1680^{\circ} \mathrm{C}$, the decarburization reaction did not receive significant development. Intensive decarburization of ferromanganese began with a residual silicon content of $0.2-0.5 \%$. By the end of the blow, the content of silicon and phosphorus increased due to loss of alloy mass associated with the burn-out of carbon and manganese.

To reduce the activity of silica in the slag, lime was added in portions into the furnace during the blowing. Lime had a beneficial effect on the decarburization of ferromanganese - melting was performed smoothly, without emissions, the blowing mode was stabilized, and the rate of carbon oxidation increased (on average by $0.02-0.05 \%$ C per minute). The final slag of the heats had the following chemical composition, \%: 
During the oxidative decarburization of highcarbon ferromanganese, the fractional concentration of phosphorus does not decrease, but rather increases because phosphorus has significantly lower chemical affinity for oxygen compared to manganese. Due to the physicochemical features of phosphorus itself - and its solutions in manganese (or in melts containing iron), the initial high-carbon ferroanganese for oxidative refining should have a lower phosphorus content than standard, since the allowed phosphorus content in medium-carbon ferromanganese regulated by the standard should not exceed $0.4 \%$.

Thermodynamic prerequisites for the interaction of manganese protoxide and silicon.

The process of reducing manganese from pure liquid manganese protoxide by silicon dissolved in manganese can be represented by the chemical reaction [14 - 16]

$2 \mathrm{MnO}_{\text {liq }}+[\mathrm{Si}] 1 \% \mathrm{sol}=2 \mathrm{Mn}_{\text {liq }}+\mathrm{SiO}_{2 \text { liq. }}$.

The temperature dependence of the Gibbs energy of the reaction, taking into account the thermdynamic data of the phase transformations of the intermediate reactions, has the form

$$
\Delta G_{T}^{0}=-98680-111,94 \cdot T+13,55 \lg T-19,85 .
$$
$10^{-3} T^{2}$, Дж г·ат Si.

The approximation of the functional dependence for the temperature range $1250-1700^{\circ} \mathrm{C}$ leads to a simplified record of the equation:

$$
\Delta G_{T}^{0}=-47000+91,45 \cdot T
$$

For more complete thermodynamic analysis of the silicothermal process, it should be taken into account that the reduction of manganese for metallic manganese and medium-carbon ferromanganese does not occur from pure manganese protoxide, but from manganese-silicate melts, for which one can accept the existence of both Mn2SiO4 (an analogue of the natural mineral tephroite) and $\mathrm{MnSiO}_{3}$ (rhodonite). Reactions for the reduction of mangaese from silicate melts have the form:

$\mathrm{Mn}_{2} \mathrm{SiO}_{4}+[\mathrm{Si}] 1 \% \mathrm{sol}=2 \mathrm{Mn}_{\text {liq }}+2 \mathrm{SiO}_{2 \text { liq }}$,

$\mathrm{MnSiO}_{3}+[\mathrm{Si}] 1 \% \mathrm{sol}=2 \mathrm{Mn}_{\text {liq }}+3 \mathrm{SiO}_{2 \text { liq }}$.

The introduction of calcium oxide into the system $\mathrm{MnO}-\mathrm{SiO} 2$ melt increases the thermodynamic conditions for a more complete manganese reduction due to an increase of manganese protoxide activity and a decrease of silicon activity in the slag. Incom?-

lete reaction to equilibrium low concentrations of $\mathrm{MnO}$ in the slag during the process is due to both a decrease in the activity of manganese protoxide and the activity of silicon dissolved in manganese.

Scientific novelty.Taking into consideration the high affinity of silicon for oxygen, the physical and chemical basis for the production of medium-carbon ferromanganese, as well as metallic manganese and low-carbon ferromanganese, is the process of the interaction of manganese oxides of a certain basicity slag melt with silicon dissolved in ferromanganese (manganese), that is, as combined reduction -refining process to produce manganese ferroalloys with a given silicon content standard.
The technology of silicothermic reduction of manganese oxides from slag was tested in a bottomblown converter. The experimental melts were carried out in a 15-ton converter with three bottom tuyeres of the pipe-in-pipe type made of copper and stainless pipes. Converter is lined with periclase-chromite refractory material. To melt $\mathrm{MnC} 17$ grade silicomanganese, an arc furnace was used, which was also lined with periclase-chromite brick. After the $\mathrm{MnC} 17$ was melted and heated to temperatures equal to $1620-1630^{\circ} \mathrm{C}$, the melt was poured into the converter with the help of a transfer ladle. Freshly calcined lime in an amount of $20 \mathrm{~kg} / \mathrm{t}$ was added to the hot converter, on its heath, before liquid silicomanganese was poured off.

For 5-6 minutes, in order to heat the metal bath, oxygen was injected into the converter at intensity of $0.98-1.02 \mathrm{~m}^{3} / \mathrm{t} \cdot \mathrm{min}$. together with natural gas, intensity of which was of $7-10 \%$ of the oxygen consumption. During this period, the metal was heated to temperatures of $1670-1680^{\circ} \mathrm{C}$. Then argon blowing was introduced, supplied both by the central tuyere channels and by the peripheral ones with a total intensity of 0.7 $\mathrm{m}^{3} / \mathrm{t} \cdot \min$. When switching to blowing the converter bath with neutral gas, the fluxed agglomerate of the following composition: MP - 33.9\%; SiO2 - 14.8\%; $\mathrm{CaO}-28.3 \%$ was added to the converter. During this period, the temperature of the metal bath of the converter decreased to $1320-1340^{\circ} \mathrm{C}$.

Then, to preheat the melt, a 6-7 minute oxygen blowing was used. During this period, the metal was heated to a temperature of $1600-1620^{\circ} \mathrm{C}$. After preheating the alloy, neutral gas blowing was applied again. Freshly calcined lime and fluxed agglomerate were again added to the converter. Then neutral gas was blown for 7-9 minutes. At the same time, the metal temperature was decreasing to $1300-1320^{\circ} \mathrm{C}$. The output of the melt was carried out to a mould lined with chromomagnesite brick through the mouth of the converter.

In general, the refining process in the bottomblowing converter took place calmly, without any emissions and slashings. Slag throughout the blowing was rarely unstable, and its basicity $((\mathrm{CaO} \mathrm{MgO}) /$ $\mathrm{SiO} 2)$ at the end of the refining period was not less than 1.2-1.3. The content of silicon in the metal in the ladle was $1.60-1.38 \%$.

\section{Conclusions}

When melt is heated by oxygen blowing, predominant oxidation of silicon occurs. Its presence in the metal practically blocks the oxidation of manganese. Since oxygen is an assimilating gas, the processes of mixing the components of the converter bath and the reduction of manganese oxides at the metal-slag interface do not receive appropriate development during blowing.

Heats of medium-carbon ferromanganese in a bottom-blown converter are characterized by a stable chemical composition and they almost completely meet the requirements for this type of alloy. A slight 
excess of the concentration of silicon in the metal on a number of heats can be easily eliminated by additional blowing of the bath with oxygen at the final stage of refining.
The behavior of phosphorus in these heats has not controlled. The content of P2O5 in the final slag is $0.1 \%$. To achieve acceptable concentrations of phosphorus in the metal, it is necessary to use lowphosphorous initial charge materials.

\section{Список літератури}

1. Дашевский В.Я., Кацнельсон А.М., Макарова Н.Н., Кашин В.И. // Докл.АН.1995.Т.345.№1. С.75-78.

2. Гасик М.И. Марганец. -М.: Металлургия, 1992. - 608 с.

3. Витусевич В.Т. Термодинамические свойства жидких сплавов Mn-C / В.Т. Витусевич, А. Билецкий, В. Шумихин // Изв. АН СССР. Металл. - 1988. - №6. - С. 26-29.

4. Острик П.Н. Металлургия губчатых и порошковых материалов / П.Н. Острик, М. Гасик, В. Пирог. - К .: Техника, 1992. - 128 с.

5. Кацнельсон А.М. Активность марганца и углерода в расплавах марганца и углерода при 1628 К / А.М. Кацнельсон, Ф. Цукихаши, Н. Сано // Тезисы докладов научно-технической конференции «Современное состояние и перспективы электротермического производства ферросплавов. - Днепропетровск. - 1994. - С. 19-20.

6. Садовник Ю.В. Шлакообразование и температурный режим при выплавке среднеуглеродистого ферромарганца с донным дутьем / Ю.В. Садовник, В. Мураховский, В.А. Сударушкин [и др.] // Металлургия и коксохимия. - К.: Техника. - 1986. - С. 61-65. 6.

7. Григорович К.П., Боголюбов В.А., Елютин В.П., Самарин А.М., Языков В.А. Ферросплавы: теория и практика выплавки ферросплавов в электрических печах. ОНТИ НКТП СССР, 1934.

8. Боголюбов В.А. Обезуглероживание ферромарганца в электропечи. - М .: Госмашметиздат, 1933.-27 с.

9. Толстогузов Н. В. Теоретические основы и технология плавки кремния и марганцевых сплавов / Н. В. Толстогузов. - М.: Металлургия, 1992. - 238 с.

10. Дуррер Р. Металлургия фрерросплавов / Р. Дуррер, Г. Фолкерт. Пер. с нем. под научной редакцией д.т.н. М.И. Гасика, д.Т.н. Б.И. Емлина, д.т.н. С.И. Хитрика. - М .: Металлургия, 1976. - 480 с.

11. Обезуглероживание расплава марганца. Дашевский В.Я., Юсфин Ю.С., Александров А.А., Подгородецкий Г.С., Губанов В.И. Металлургические технологии. Известия высших учебных заведений. Черная металлургия. №7. 2012.S.15-17.

12. Мизин В.Г. Рафинирование фрерромарганца продувкой газообразным кислородом / В.Г. Мизин, В. Хобот, Ю.А. Данилович // Сталь. - 1983. - №5. - С. 12-15.

13. Марганец. Химическая энциклопедия [в 5 т.] - М .: Советская энциклопедия. -Т. 2. - 1988. - С. 647-648.

14. Садовский Н.Г. Влияние температуры на равновесие жидкого марганца с оксидным расплавом системы Mn-O-Si, насыщенным кремнеземом / Н.Г. Садовский, М. Гасик // Металлургия и коксохимия. - 1978. - Вып. 56. - C. 46-49.

15. Величко А.Г. Силикотермический метод получения среднеуглеродистого ферромарганца в конвертере с донным дутем / А.Г. Величко, Ду Юньшен, А.В. Лысаков // Металлургическая и горнорудная промышленность. - 2015. - №3. - С. 23-25.

16. Величко А.Г. Исследование термодинамики восстановления закиси марганца силикомарганцем при получении среднеуглеродистого ферромарганца / А.Г. Величко, Ду Юншен, М.И. Гасик // Металлургическая и горнорудная промышленность. - 2015. - №4. - С. 34-37.

\section{Referens}

1. Dashevskij V.Ya., Kacznel`son A.M., Makarova N.N., Kashin V.I. // Dokl.AN.1995.T.345.\#1. S.75-78.

2. Gasik M.I. Marganecz. -M.: Metallurgiya, 1992. - 608 s.

3. Vitusevich V.T. Termodinamicheskie svojstva zhidkikh splavov Mn-C / V.T. Vitusevich, A. Bileczkij, V. Shumikhin // Izv. AN SSSR. Metall. - 1988. - \#6. - S. 26-29.

4. Ostrik P.N. Metallurgiya gubchaty `kh i poroshkovy`kh materialov / P.N. Ostrik, M. Gasik, V. Pirog. - K .: Tekhnika, 1992. - $128 \mathrm{~s}$.

5. Kacznel`son A.M. Aktivnost’ margancza i ugleroda v rasplavakh margancza i ugleroda pri 1628 K / A.M. Kacznel`son, F. Czukikhashi, N. Sano // Tezisy` dokladov nauchno-tekhnicheskoj konferenczii «Sovremennoe sostoyanie i perspektivy`e lektrotermicheskogo proizvodstva ferrosplavov. - Dnepropetrovsk. - 1994. - S. 1920.

6. Sadovnik Yu.V. Shlakoobrazovanie i temperaturny`j rezhim pri vy plavke sredneuglerodistogo ferromargancza s donny`m dut`em / Yu.V. Sadovnik, V. Murakhovskij, V.A. Sudarushkin [i dr.] // Metallurgiya i koksokhimiya. - K.: Tekhnika. - 1986. - S. 61-65. 6.

7. Grigorovich K.P., Bogolyubov V.A., Elyutin V.P., Samarin A.M., Yazy`kov V.A. Ferrosplavy`: teoriya i praktika vy` plavki ferrosplavov v e'lektricheskikh pechakh. ONTI NKTP SSSR, 1934.

8. Bogolyubov V.A. Obezuglerozhivanie ferromargancza v e`lektropechi. - M .: Gosmashmetizdat, $1933 .-27$ s.

9. Tolstoguzov N. V. Teoreticheskie osnovy` i tekhnologiya plavki kremniya i marganczevy`kh splavov / N. V. Tolstoguzov. - M.: Metallurgiya, 1992. - $238 \mathrm{~s}$.

10. Durrer R. Metallurgiya ferrosplavov / R. Durrer, G. Folkert. Per. s nem. pod nauchnoj redakcziej d.t.n. M.I. Gasika, d.t.n. B.I. Emlina, d.t.n. S.I. Khitrika. - M .: Metallurgiya, 1976. - 480 s.

11. Obezuglerozhivanie rasplava margancza. Dashevskij V.Ya., Yusfin Yu.S., Aleksandrov A.A., Podgorodeczkij G.S., Gubanov V.I. Metallurgicheskie tekhnologii. Izvestiya vy`sshikh uchebny`kh zavedenij. Chernaya metalurgiya. \#7. 2012.S.15-17. 
12. Mizin V.G. Rafinirovanie ferromargancza produvkoj gazoobrazny`m kislorodom / V.G. Mizin, V. Khobot, Yu.A. Danilovich // Stal’. - 1983. - \#5. - S. 12-15.

13. Marganecz. Khimicheskaya e`ncziklopediya [v 5 t.] - M .: Sovetskaya e`ncziklopediya. -T. 2. - 1988. - S. 647648.

14. Sadovskij N.G. Vliyanie temperatury` na ravnovesie zhidkogo margancza s oksidny`m rasplavom sistemy`Mn-OSi, nasy`shhenny`m kremnezemom / N.G. Sadovskij, M. Gasik // Metallurgiya i koksokhimiya. - 1978. - Vy`p. 56. - S. 46-49.

15. Velichko A.G. Silikotermicheskij metod polucheniya sredneuglerodistogo ferromargancza $v$ konvertere $s$ donny`m dutem / A.G. Velichko, Du Yun`shen, A.V. Ly`sakov // Metallurgicheskaya i gornorudnaya promy`shlennost`. - 2015. - \#3. - S. 23-25.

16. Velichko A.G. Issledovanie termodinamiki vosstanovleniya zakisi margancza silikomarganczem pri poluchenii sredneuglerodistogo ferromargancza / A.G. Velichko, Du Yunshen, M.I. Gasik // Metallurgicheskaya i gornr?dnaya promy`shlennost`. - 2015. - \#4. - S. 34-37.

Стаття поступила:14.12.2019 